\title{
Lactobacillus crustorum sp. nov., isolated from two traditional Belgian wheat sourdoughs
}

Correspondence

Ilse Scheirlinck

Ilse.Scheirlinck@ugent.be
Ilse Scheirlinck, ${ }^{1,2}$ Roel Van der Meulen, ${ }^{3}$ Ann Van Schoor, ${ }^{1,2}$ Geert Huys, ${ }^{1}$ Peter Vandamme, ${ }^{1}$ Luc De Vuyst ${ }^{3}$ and Marc Vancanneyt ${ }^{2}$

\author{
${ }^{1}$ Laboratory of Microbiology, Department of Biochemistry, Physiology and Microbiology, \\ Ghent University, K. L. Ledeganckstraat 35, B-9000 Ghent, Belgium \\ ${ }^{2}$ BCCM/LMG Bacteria Collection, Department of Biochemistry, Physiology and Microbiology, \\ Ghent University, K. L. Ledeganckstraat 35, B-9000 Ghent, Belgium \\ ${ }^{3}$ Research Group of Industrial Microbiology and Food Biotechnology, Department of Applied \\ Biological Sciences and Engineering, Vrije Universiteit Brussel, Pleinlaan 2, B-1050 Brussels, \\ Belgium
}

\begin{abstract}
A polyphasic taxonomic study of the lactic acid bacteria (LAB) population in three traditional Belgian sourdoughs, sampled between 2002 and 2004, revealed a group of isolates that could not be assigned to any recognized LAB species. Initially, sourdough isolates were screened by means of $(G T G)_{5}-P C R$ fingerprinting. Four isolates displaying unique $(G T G)_{5}-P C R$ patterns were further investigated by means of phenylalanyl-tRNA synthase ( $p h e S$ ) gene sequence analysis and represented a bifurcated branch that could not be allocated to any $L A B$ species present in the in-house pheS database. Their phylogenetic affiliation was determined using 16S rRNA gene sequence analysis and showed that the four sourdough isolates belong to the Lactobacillus plantarum group with Lactobacillus mindensis, Lactobacillus farciminis and Lactobacillus nantensis as closest relatives. Further genotypic and phenotypic studies, including whole-cell protein analysis (SDS-PAGE), amplified fragment length polymorphism (AFLP) fingerprinting, DNA-DNA hybridization, DNA G $+C$ content analysis, growth characteristics and biochemical features, demonstrated that the new sourdough isolates represent a novel Lactobacillus species for which the name Lactobacillus crustorum sp. nov. is proposed. The type strain of the new species is LMG $23699^{\top}\left(=\right.$ CCUG $\left.53174^{\top}\right)$.
\end{abstract}

Sourdough consists of a natural microbial consortium in which the fermentation activities of lactic acid bacteria (LAB) and yeasts determine the typical characteristics of baked goods (Hammes \& Gänzle, 1998). Both groups of micro-organisms, present in the flour or added as a starter, contribute to the sourdough fermentation. While yeasts are primarily responsible for the leavening process, LAB mainly contribute to lactic fermentation, proteolysis, synthesis of aromatic compounds, and anti-mould and anti-ropiness activity (Gobbetti, 1998; Hammes \& Gänzle, 1998). Lactobacillus species dominate in sourdough due to their competitiveness and adaptation to the specific environmental

\footnotetext{
Abbreviation: $L A B$, lactic acid bacteria.

The GenBank/EMBL/DDBJ accession numbers for the 16S rRNA gene sequences of strains LMG 23699' ${ }^{\top}$, LMG 23701, LMG 23702 and R-30103 are AM285450, AM285454, AM285451 and AM285452, respectively, and for the pheS gene sequences AM285025, AM285027, AM285028 and AM285449, respectively.
}

A figure showing data from numerical analysis of the protein profiles is available with the online version of this paper. conditions (De Vuyst \& Neysens, 2005). The majority of recently described species isolated from sourdoughs are members of the Lactobacillus plantarum group and Lactobacillus brevis group, such as Lactobacillus nantensis (Valcheva et al., 2006) and Lactobacillus namurensis (Scheirlinck et al., 2007), respectively. The phylogenetic relatedness of species within these groups is strongly based on $16 \mathrm{~S}$ rRNA gene sequence analysis (Rossello-Mora \& Amann, 2001); however, in other bacterial taxa, the high degree of conservation of the $16 \mathrm{~S}$ rRNA gene complicates the differentiation of such closely related species (Cooper \& Feil, 2004). Recent work has indicated that the proteinencoding gene phenylalanyl-tRNA synthase (pheS) is a promising tool for delineation and identification of Lactobacillus species (S. M. Naser, P. S. R. Dawyndt, B. Hoste, D. Gevers, K. Vandemeulebroecke, I. Cleenwerck, M. Vancanneyt \& J. Swings, unpublished; Vancanneyt et al., 2006).

In the period 2002-2004, we obtained a group of Lactobacillus isolates from traditional Belgian wheat sourdoughs that could not be assigned to any hitherto known species. In 
the present study, phenotypic and genotypic evidence is presented to support the description of this group as a novel Lactobacillus species for which the name Lactobacillus crustorum sp. nov. is proposed.

The wheat sourdough samples used in this study originate from biodiversity studies performed at two different Belgian artisan bakeries. Both wheat sourdoughs were incubated at $28-30{ }^{\circ} \mathrm{C}$ and used for the production of cookies, baguettes, hard rolls and bread. Sourdough samples were taken aseptically, stored at $4{ }^{\circ} \mathrm{C}$ and analysed within $24 \mathrm{~h}$. Sourdough samples were suspended $(1: 10, \mathrm{w} / \mathrm{v})$ and serially diluted in peptone-physiological solution (PPS) $[0.1 \%(\mathrm{w} / \mathrm{v})$ bacteriological peptone (Oxoid) and $0.85 \%(\mathrm{w} / \mathrm{v}) \mathrm{NaCl}$. Sample dilutions were incubated at 30 and $37^{\circ} \mathrm{C}$ under aerobic and anaerobic conditions on MRS5 agar containing $0.1 \mathrm{~g}$ cycloheximide $1^{-1}$ (Meroth et al., 2003). Colonies were picked, checked for bacteriological purity and stored in Microbank tubes (Pro-Lab Diagnostics) at $-80^{\circ} \mathrm{C}$. Isolates LMG 23699 ${ }^{\mathrm{T}}$, LMG 23701, LMG 23702 and R-30103 were cultured in an aerobic atmosphere at $30^{\circ} \mathrm{C}$. Isolates LMG 23701 and LMG 23702 originate from a wheat sourdough produced in the province of Namur, Belgium, that was sampled in 2002. Isolates LMG $23699^{\mathrm{T}}$ and R-30103 were recovered from a wheat sourdough sampled in 2004 and 2005 , respectively. The latter sourdough was produced in the province of Oost-Vlaanderen, Belgium. Gram-staining, cell morphology, catalase activity and all further experiments were performed with cells cultivated for $24 \mathrm{~h}$ on MRS5 medium and incubation at $30^{\circ} \mathrm{C}$ under aerobic conditions, unless otherwise indicated.

The original collection of sourdough isolates obtained during the biodiversity studies was initially screened by means of rep-PCR fingerprinting. For rep-PCR analysis, total DNA was extracted from single colonies grown on MRS5 agar by alkaline lysis. A small portion of one colony was resuspended in $20 \mu \mathrm{l}$ lysis buffer $(2.5 \mathrm{ml} 10 \%$ SDS, $5.0 \mathrm{ml} 1 \mathrm{M} \mathrm{NaOH}, 92.5 \mathrm{ml}$ Milli-Q water). The mixture was heated at $95^{\circ} \mathrm{C}$ for $15 \mathrm{~min}$, cooled immediately on ice and after a short centrifugation at high speed, $180 \mu \mathrm{l}$ sterile Milli-Q water was added. Subsequently, the mixture was centrifuged at $13000 \mathrm{~g}$ for $5 \mathrm{~min}$ and stored at $-20^{\circ} \mathrm{C}$. If the alkaline lysis method was not able to produce good quality rep-PCR profiles, a phenol/chloroform method was used, as described by Gevers et al. (2001). The rep-PCR oligonucleotide primer used in this study was $(\mathrm{GTG})_{5}\left(5^{\prime}\right.$ GTGGTGGTGGTGGTG-3') (Versalovic et al., 1994). The conditions for amplification and gel electrophoresis were as reported by Versalovic et al. (1994). The (GTG) 5 -PCR profiles were visualized after staining with ethidium bromide under UV light, followed by digital image capturing using a CCD camera. The resulting fingerprints were analysed using the BioNumerics V4.0 software package (Applied Maths). Isolates were tentatively assigned to a given species when high similarities between the $(G T G)_{5^{-}}$ PCR fingerprints of isolates and reference strains of typical sourdough species were obtained. A separate $(G T G)_{5}$-PCR cluster containing 11 sourdough isolates from two different bakeries could not be allocated to any species in the $(\mathrm{GTG})_{5}$-PCR reference framework (data not shown). Four isolates from this cluster that produced a unique $(\mathrm{GTG})_{5^{-}}$ PCR band pattern, i.e. LMG $23699^{\mathrm{T}}$, LMG 23701, LMG 23702 and R-30103, were selected for further polyphasic characterization.

The taxonomic position of the four selected sourdough isolates was first investigated using pheS gene sequence analysis (Naser et al., 2005). Genomic DNA was extracted as described by Gevers et al. (2001). The primers for pheS sequencing were PheS-21-F and PheS-23-R, using amplification conditions and sequencing reactions as described by Naser et al. (2005). Sequences were imported into the BioNumerics V4.0 software, aligned and compared using the neighbour-joining method with available sequences of nearly all recognized Lactobacillus species. All four isolates constituted a separate sub-branch in the Lactobacillus plantarum group, showing sequence similarities below $90 \%$ with the other members of the group (Fig. 1). Isolates LMG $23699^{\mathrm{T}}$, LMG 23701 and R-30103 shared $100 \%$ sequence similarity, whereas isolate LMG 23702 showed $90.2 \%$ pheS sequence similarity with the other three sourdough isolates. Interspecies gaps in lactobacilli normally exceed 7\% (S. M. Naser, P. S. R. Dawyndt, B. Hoste, D. Gevers, K. Vandemeulebroecke, I. Cleenwerck, M. Vancanneyt \& J. Swings, unpublished), which suggested that the four sourdough isolates represented one or possibly two new Lactobacillus species.

The phylogenetic position of all isolates was determined by complete 16S rRNA gene sequence analysis. Genomic DNA was extracted as described above. 16S rRNA gene amplification, purification and sequencing were performed as described previously (Vancanneyt et al., 2006). The obtained sequences (continuous stretches of $1519 \mathrm{bp}$ ) were deposited in, and aligned and clustered with sequences from the EMBL database. A phylogenetic tree was constructed using the neighbour-joining method and the BioNumerics V4.0 software package. Unknown bases were discarded for analysis. The statistical reliability of the tree was evaluated by bootstrap analysis of 500 replicates and the tree topology was confirmed using maximum-parsimony and maximumlikelihood. 16S rRNA gene sequence analysis indicated that the four sourdough isolates clearly belong to the Lactobacillus plantarum group. Isolate LMG $23699^{\mathrm{T}}$ is most closely positioned to Lactobacillus nantensis (LMG $23510^{\mathrm{T}}$ ), Lactobacillus mindensis (LMG $21932^{\mathrm{T}}$ ) and Lactobacillus farciminis $\left(\mathrm{LMG} 9200^{\mathrm{T}}\right.$ ), showing $16 \mathrm{~S}$ rRNA gene sequence similarities of $98.4,98.9$ and $99.3 \%$, respectively (Fig. 2). All four new isolates shared more than $99.5 \% 16 \mathrm{~S}$ rRNA gene sequence similarity, which contrasted with the separate position of isolate LMG 23702 revealed by pheS sequence analysis.

The sourdough LAB isolates were also investigated using SDS-PAGE of cellular proteins. Extraction and gel electrophoresis were performed according to the method 


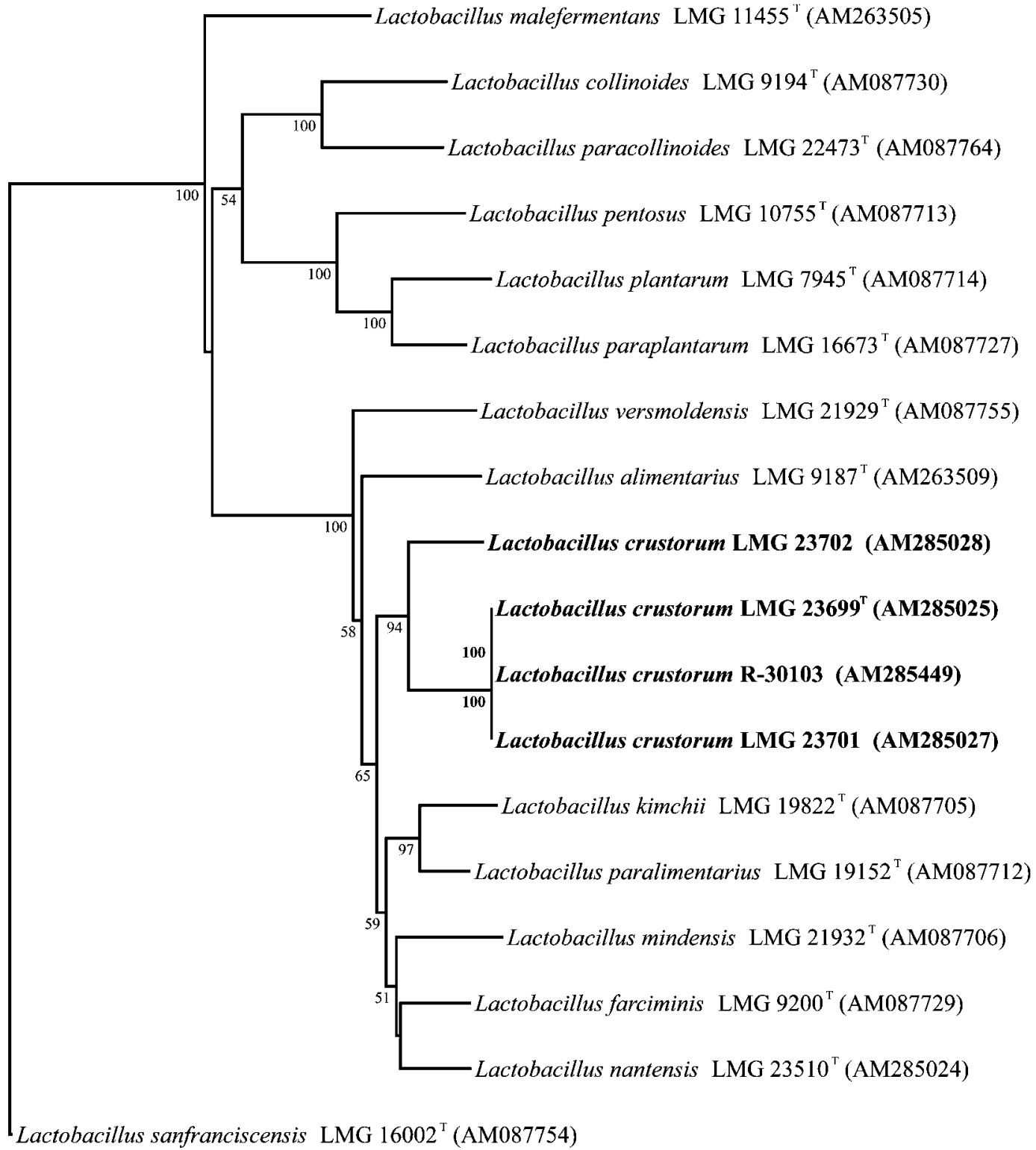

Fig. 1. Neighbour-joining tree showing the relationships of pheS sequence data of the sourdough isolates Lactobacillus crustorum LMG 23699 ${ }^{\top}$, LMG 23701, LMG 23702 and R-30103 with reference strains of the Lactobacillus plantarum group. Lactobacillus sanfranciscensis (LMG $16002^{\top}$ ) was used as outgroup. Bootstrap values (based on 500 replications) at or above $50 \%$ are indicated at the branch points. Bar, 10 substitutions per 100 nt positions.

described by Pot et al. (1994) for Gram-positive bacteria. Densitometric digitization of patterns was performed using an LKB 2202 Ultrascan Laser Densitometer. Normalization of densitometric traces was performed using the GELCOMPAR version 4.2 software (Applied Maths). Numerical analysis with profiles available in an extensive in-house database was performed using the Pearson product moment correlation coefficient and the unweighted pair-group method using arithmetic averages (UPGMA) with BioNumerics V4.0 software. Among the protein profiles of the four sourdough isolates, notable differences were observed in the position and intensity of the dominant bands situated in a molecular mass range of 25-35 kDa. Numerical analysis of the protein profiles, omitting the latter zone, resulted in the delineation of one distinct branch for the four sourdough isolates (see supplementary Fig. S1 with the online version of this paper). Between isolates LMG $23699^{\mathrm{T}}$ and R-30103, only minor differences were observed in the intensity of dominant bands which could suggest that both isolates are subcultures of a diverging clone. 


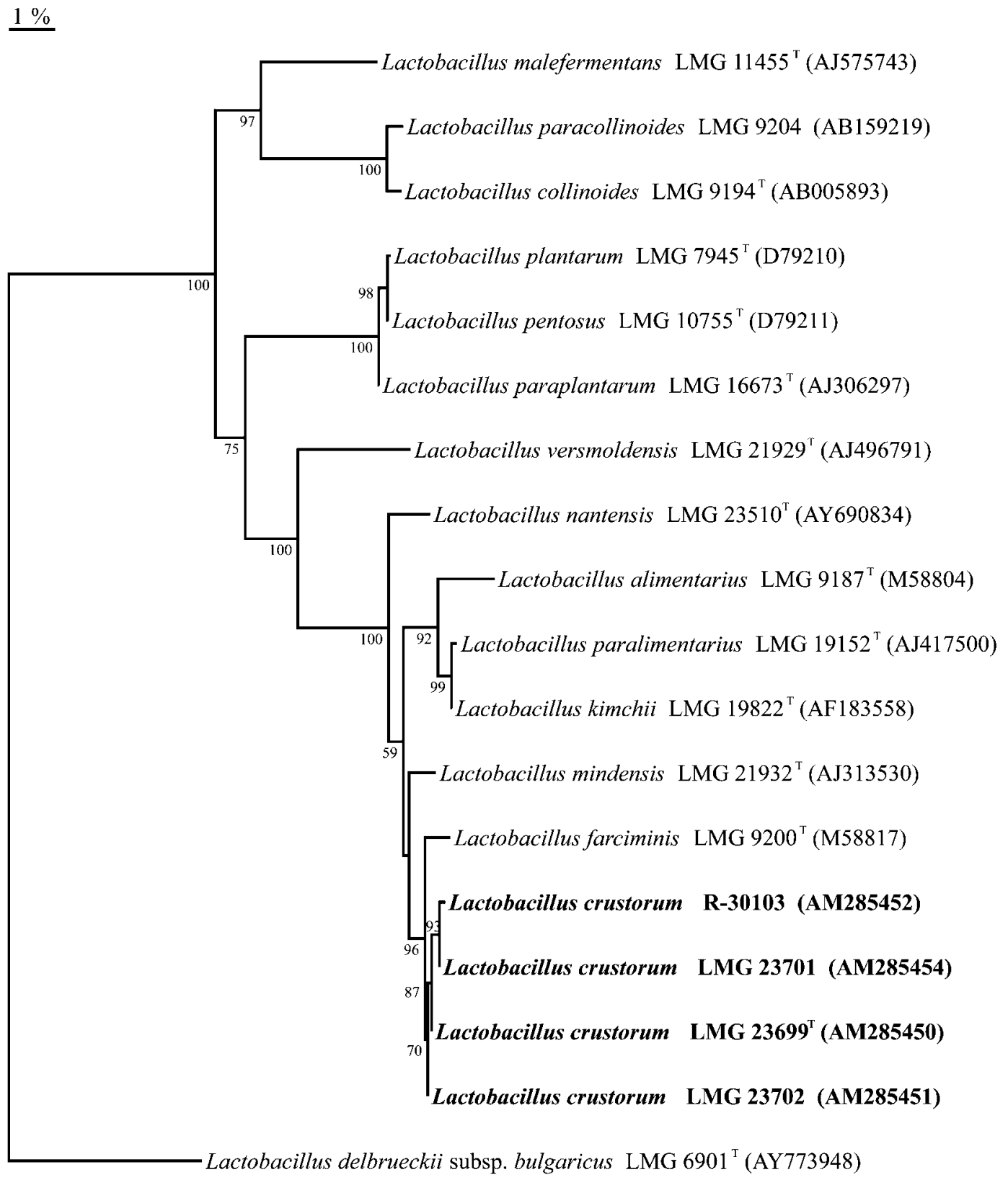

Fig. 2. Phylogenetic tree derived from $16 \mathrm{~S}$ rRNA gene sequence analysis showing the phylogenetic position of Lactobacillus crustorum LMG 23699 ${ }^{\top}$, LMG 23701, LMG 23702 and R-30103 among related taxa. The tree was generated by the neighbourjoining method and Lactobacillus delbrueckii subsp. bulgaricus (LMG 6901 ${ }^{\top}$ ) was used as outgroup. Bootstrap values (based on 500 replications) at or above $50 \%$ are indicated at the branch points. Bar, 1 substitution per 100 nt positions.

Further genotypic characterization and differentiation of the four new isolates was performed using amplified fragment length polymorphism (AFLP) fingerprinting of whole genomes. Extraction and purification of total genomic DNA was done as described above. AFLP analysis was performed according to the protocol of Thompson et al. (2001) with several modifications. Total DNA was digested with EcoRI and TaqI restriction enzymes. Fragments were amplified using the primers E01 (5'-GACTGCGTACCAATTCA-3') and T01 (5'-CGATGAGTCCTGACCGAA-3'). The resulting electrophoretic profiles were normalized using the GeneScan 3.1 software (Applera), and tables of peaks, containing fragments of 50-536 bp, were transferred into the BioNumerics V4.0 software. AFLP patterns were compared with profiles of $\mathrm{LAB}$ reference taxa using the Dice coefficient and UPGMA linkage. Cluster analysis of the AFLP band patterns confirmed the unique taxonomic position of isolates LMG 23699 , LMG 23701, LMG 23702 
and R-30103. Also, we observed that the AFLP pattern of isolate LMG 23702 was the most divergent compared to the other three sourdough isolates. Although isolates LMG $23699^{\mathrm{T}}$ and R-30103 displayed highly similar fingerprints, AFLP analysis allowed strain differentiation among the four new isolates and thus excluded clonal relatedness (Fig. 3).

For the determination of $\mathrm{G}+\mathrm{C}$ content, DNA was enzymically degraded into nucleosides as described by Mesbah et al. (1989). Genomic DNA was extracted as described above. The nucleoside mixture was separated by HPLC using a Waters SymmetryShield C8 column maintained at $37^{\circ} \mathrm{C}$. The solvent was $0.02 \mathrm{M}\left(\mathrm{NH}_{4}\right) \mathrm{H}_{2} \mathrm{PO}_{4}(\mathrm{pH} 4.0)$ with $1.5 \%$ acetonitrile. Non-methylated $\lambda$-phage DNA (Sigma) was used as the calibration reference. The DNA G $+\mathrm{C}$ contents of the strains LMG 23699 ${ }^{\mathrm{T}}$, LMG 23701, LMG 23702 and R-30103 were $35,36,35$ and 35 mol\%, respectively. These values are within the range reported for the Lactobacillus plantarum group (34-46 mol\%) (Ehrmann et al., 2003).

DNA-DNA hybridizations were performed between strains LMG 23699 , LMG 23701, LMG 23702 and R-30103 and the type strains of the seven most closely related species, i.e. Lactobacillus farciminis, Lactobacillus nantensis, Lactobacillus mindensis, Lactobacillus kimchii, Lactobacillus paralimentarius, Lactobacillus alimentarius and Lactobacillus versmoldensis (Figs 1 and 2). DNA was extracted from $0.75-1.25 \mathrm{~g}$ (wet wt) cells using the protocol described by Gevers et al. (2001) with the following modifications. Volumes were increased tenfold for large-scale application. After the addition of $20 \%$ SDS and glass beads, cells were mixed for $30 \mathrm{~s}$. Subsequently, $16.5 \mathrm{ml}$ TE buffer $(10 \mathrm{mM}$ Tris/HCl, $100 \mathrm{mM}$ EDTA, $\mathrm{pH} \mathrm{8.0)} \mathrm{and} 5 \mathrm{ml} 5 \mathrm{M} \mathrm{NaCl}$ were added, followed by $10 \mathrm{~min}$ incubation at $65^{\circ} \mathrm{C}$. The chloroform/isoamylalcohol extraction, and ethanol and RNase treatment were performed as described by Marmur (1961). DNA-DNA hybridizations were performed with biotin-labelled probes in microplate wells (Ezaki et al., 1989), using an HTS7000 Bio Assay Reader (Perkin Elmer) for the fluorescence measurements. The hybridization temperature was $34{ }^{\circ} \mathrm{C}$ in the presence of $50 \%$ formamide. Reciprocal experiments were performed for every pair of strains and standard deviation values ranged from 0.3 to 12 . DNA-DNA binding values between strain LMG $23699^{\mathrm{T}}$ and the type strain of Lactobacillus alimentarius (LMG $9187^{\mathrm{T}}$ ), Lactobacillus farciminis (LMG $9200^{\mathrm{T}}$ ), Lactobacillus nantensis $\left(\mathrm{LMG} 23510^{\mathrm{T}}\right)$, Lactobacillus paralimentarius $\left(\mathrm{LMG} 19152^{\mathrm{T}}\right.$ ), Lactobacillus mindensis (LMG $21932^{\mathrm{T}}$ ), Lactobacillus kimchii $\left(\mathrm{LMG} \mathrm{19822^{ \textrm {T } }}\right.$ ) and Lactobacillus versmoldensis $\left(\mathrm{LMG} 21929^{\mathrm{T}}\right.$ ) were $35,33,31,31,30,26$ and $14 \%$, respectively. These values are well below the threshold of $70 \%$ suggested for species delineation (Stackebrandt \& Goebel, 1994), indicating that LMG $23699^{\mathrm{T}}$ represents a novel species in the genus Lactobacillus. Furthermore, DNA-DNA hybridizations were performed between strain LMG $23699^{\mathrm{T}}$ and strains LMG 23701, LMG 23702 and R-30103. Hybridization values were above the $70 \%$ threshold (range $72-96 \%$ ), indicating that all strains belong to the same species. DNA-DNA binding values were lowest between strain LMG 23702 and strains LMG $23699^{\mathrm{T}}$, LMG 23701 and R-30103 (range 72-77\%), which is in line with the slightly aberrant position of the former strain in pheS sequencing and AFLP analysis (Figs 1 and 3). Despite this, polyphasic taxonomic evidence collectively indicates that strain LMG 23702 is sufficiently close to the other three sourdough strains to be considered a member of the same species.

Growth characteristics of strains LMG $23699^{\mathrm{T}}$, LMG 23701, LMG 23702 and R-30103 were determined in MRS broth (pH 5.4) (de Man et al., 1960). Growth was tested at 15 and $45^{\circ} \mathrm{C}$ and in the presence of 5, 6 and $7 \% \mathrm{NaCl}$. Aerobic and anaerobic growth and production of gas from $2 \%$ glucose and $2 \%$ gluconate in MRS-broth ( $\mathrm{pH} 5.4$, without triammonium citrate) was investigated. Arginine hydrolysis was tested in a medium containing $0.5 \%$ tryptone, $0.5 \%$ yeast extract, $0.3 \% \mathrm{~L}$-arginine, $0.05 \%$ glucose and $0.2 \% \mathrm{~K}_{2} \mathrm{HPO}_{4}$ ( $\mathrm{pH}$ 7.0), with methyl orange as indicator. The isomeric type of lactate was determined enzymically (R-Biopharm).

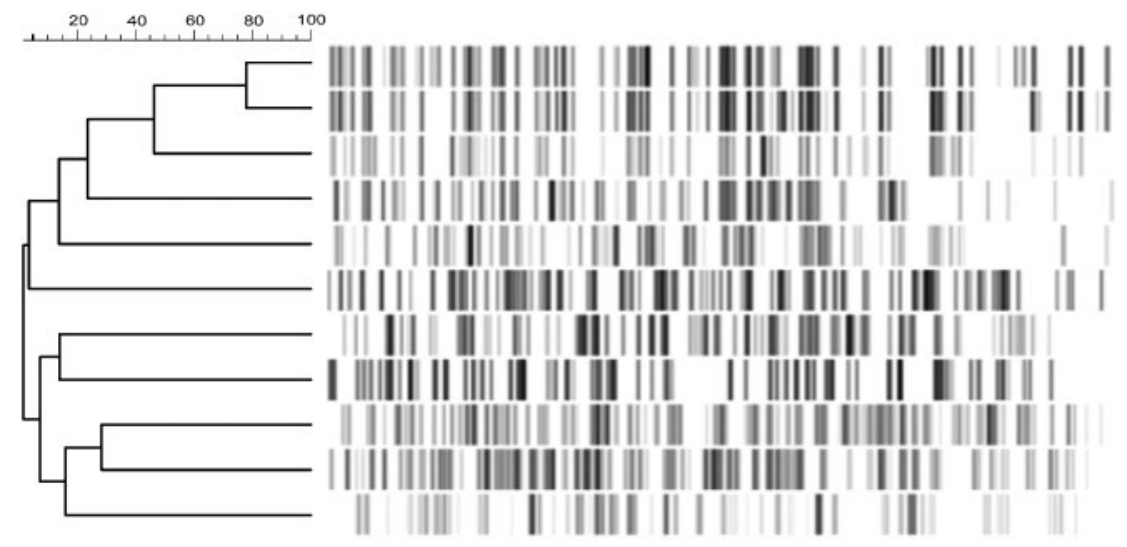

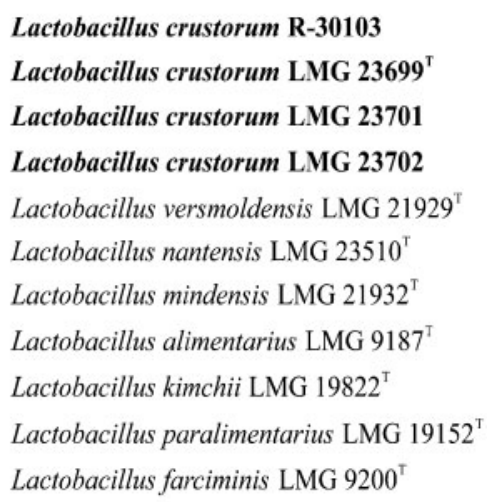

Fig. 3. Cluster analysis of digitized AFLP band patterns of $L$. crustorum and closest phylogenetic relatives. The corresponding dendrogram was constructed from the UPGMA linkage of Dice coefficients. 
The carbohydrate fermentation patterns of the strains were determined using the API 50 CHL system (bioMérieux), following the manufacturer's instructions with strains cultivated at $37^{\circ} \mathrm{C}$. A detailed phenotypic description is given below and characteristics differentiating the new species from its closest relatives Lactobacillus farciminis, Lactobacillus nantensis and Lactobacillus mindensis are summarized in Table 1.

Considering all evidence from the polyphasic taxonomic study, a novel species, Lactobacillus crustorum sp. nov., is proposed for strains LMG $23699^{\mathrm{T}}$, LMG 23701, LMG 23702 and R-30103.

\section{Description of Lactobacillus crustorum sp. nov.}

Lactobacillus crustorum (crus.tor'um. L. gen. pl. n. crustorum, of breads/cakes).

Cells are Gram-positive, catalase-negative, non-motile and non-spore-forming. The rod-shaped cells occur singly or in pairs, are $2-15 \mu \mathrm{m}$ in length and $0.5-1 \mu \mathrm{m}$ wide. After $24 \mathrm{~h}$

Table 1. Phenotypic characteristics of Lactobacillus crustorum strains LMG 23699 ${ }^{\top}$, LMG 23701, LMG 23702 and $\mathrm{R}-30103$ and reference strains of their closest relatives

Strains: 1, Lactobacillus nantensis LMG $23510^{\mathrm{T}}$ (data from Valcheva et al., 2006); 2, Lactobacillus farciminis $\mathrm{LMG} 9200^{\mathrm{T}}$ (data from Reuter, 1983); 3, Lactobacillus mindensis LMG $21932^{\mathrm{T}}$ (data from Ehrmann et al., 2003); 4, Lactobacillus crustorum sp. nov. LMG $23699^{\mathrm{T}}$; 5, Lactobacillus crustorum sp. nov. LMG 23701; 6, Lactobacillus crustorum sp. nov. LMG 23702; 7, Lactobacillus crustorum sp. nov. R-30103. +, Positive after $48 \mathrm{~h}$ incubation; $(+)$, positive after 5 days incubation; -, negative; $\mathrm{w}$, weakly positive.

\begin{tabular}{|c|c|c|c|c|c|c|c|}
\hline Production of acid from: & 1 & 2 & 3 & 4 & 5 & 6 & 7 \\
\hline Ribose & $\mathrm{w}$ & - & - & - & - & - & - \\
\hline Galactose & + & + & - & + & + & + & + \\
\hline Rhamnose & - & - & - & - & - & $(+)$ & - \\
\hline Mannitol & + & - & - & - & - & - & - \\
\hline Sorbitol & + & - & - & - & - & - & - \\
\hline$\alpha$-Methyl-D-mannoside & + & - & - & - & - & - & - \\
\hline$N$-Acetylglucosamine & + & - & + & + & + & + & + \\
\hline Amygdalin & + & - & $\mathrm{W}$ & + & - & $(+)$ & + \\
\hline Arbutin & + & - & - & $(+)$ & - & - & + \\
\hline Aesculin & + & + & - & + & + & + & + \\
\hline Cellobiose & + & + & + & + & - & + & - \\
\hline Maltose & + & $\mathrm{W}$ & + & + & - & $(+)$ & + \\
\hline Lactose & + & + & - & + & + & + & + \\
\hline Melibiose & + & - & - & - & - & - & - \\
\hline Sucrose & + & + & - & - & - & - & - \\
\hline Trehalose & + & $\mathrm{W}$ & - & + & $(+)$ & $(+)$ & + \\
\hline Melezitose & - & - & - & - & - & - & - \\
\hline Raffinose & + & $\mathrm{W}$ & - & - & - & - & - \\
\hline Gentiobiose & + & - & - & + & + & + & + \\
\hline D-Tagatose & + & - & - & + & + & + & + \\
\hline
\end{tabular}

incubation on MRS5 agar, colonies are beige, slightly irregular, convex with a slightly rough surface and approximately $0.5-2 \mathrm{~mm}$ in diameter. The cells grow well in liquid or solid MRS under aerobic or anaerobic conditions. The strains grow at $15^{\circ} \mathrm{C}$ in the presence of 5,6 and $7 \% \mathrm{NaCl}$ and at $45^{\circ} \mathrm{C}$. All strains produce more than $90 \%$ of the L-lactate isomer and glucose is metabolized homofermentatively. Ammonium is not produced from arginine. No gas is produced from glucose or gluconate. All strains produce acid from galactose, glucose, fructose, mannose, $\mathrm{N}$-acetylglucosamine, aesculin and salicin, but not from glycerol, erythritol, D-arabinose, L-arabinose, ribose, D-xylose, $\mathrm{L}$-xylose, adonitol, $\beta$-methyl-D-xyloside, sorbose, dulcitol, inositol, mannitol, sorbitol, $\alpha$-methyl-D-mannoside, $\alpha$ methyl-D-glucoside, melibiose, sucrose, inulin, melezitose, raffinose, starch, glycogen, xylitol, D-turanose, D-lyxose, D-fucose, L-fucose, D-arabitol, L-arabitol, gluconate, 2ketogluconate and 5-ketogluconate. Acid production from rhamnose, amygdalin, arbutin, cellobiose, maltose, lactose, trehalose, gentiobiose and D-tagatose is strain-dependent. The DNA G $+\mathrm{C}$ content is $35-36 \mathrm{~mol} \%$.

The type strain, LMG $23699^{\mathrm{T}}$ (=CCUG $53174^{\mathrm{T}}$ ), was isolated from an artisan wheat sourdough produced in the province of Oost-Vlaanderen, Belgium.

\section{Acknowledgements}

We are grateful for the financial support of the Flemish Institute for the Promotion of Innovation by Science and Technology in Flanders (IWT), in particular the SBO project 'New Strategy for the Development of Functional and Performant Starter Cultures for Foods in Function of Food Qualitomics'. We also thank the owners and staff of the bakeries for providing the sourdough samples used in this study. The authors further acknowledge financial support from the Research Council of the Vrije Universiteit Brussel (BOF and GOA projects) and the LINK project of the Brussels Capital Region. The Fund for Scientific Research-Flanders is acknowledged for financial support and for the postdoctoral fellowship of G. H.

\section{References}

Cooper, J. E. \& Feil, E. J. (2004). Multilocus sequence typing - what is resolved? Trends Microbiol 12, 373-377.

de Man, J. C., Rogosa, M. \& Scharpe, E. (1960). A medium for the cultivation of lactobacilli. J Appl Bacteriol 23, 130-135.

De Vuyst, L. \& Neysens, P. (2005). The sourdough microflora: biodiversity and metabolic interactions. Trends Food Sci Technol 16, 43-56.

Ehrmann, M. A., Müller, M. R. A. \& Vogel, R. F. (2003). Molecular analysis of sourdough reveals Lactobacillus mindensis sp. nov. Int J Syst Evol Microbiol 53, 7-13.

Ezaki, T., Hashimoto, Y. \& Yabuuchi, E. (1989). Fluorometric deoxyribonucleic acid-deoxyribonucleic acid hybridization in microdilution wells as an alternative to membrane-filter hybridization in which radioisotopes are used to determine genetic relatedness among bacterial strains. Int J Syst Bacteriol 39, 224-229.

Gevers, D., Huys, G. \& Swings, J. (2001). Applicability of rep-PCR fingerprinting for differentiation of Lactobacillus species. FEMS Microbiol Lett 205, 31-36. 
Gobbetti, M. (1998). The sourdough microflora: interactions of lactic acid bacteria and yeasts. Trends Food Sci Technol 9, 267-274.

Hammes, W. P. \& Gänzle, M. G. (1998). Sourdough breads and related products. In Microbiology of Fermented Foods, pp. 199-216. Edited by B. J. B. Wood. London: Blackie.

Marmur, J. (1961). A procedure for the isolation of deoxyribonucleic acid from microorganisms. J Mol Biol 3, 208-218.

Meroth, C. B., Walter, J., Hertel, C., Brandt, M. J. \& Hammes, W. P. (2003). Monitoring the bacterial population dynamics in sourdough fermentation processes by using PCR-denaturing gradient gel electrophoresis. Appl Environ Microbiol 69, 475-482.

Mesbah, M., Premachandran, U. \& Whitman, W. B. (1989). Precise measurement of the $\mathrm{G}+\mathrm{C}$ content of deoxyribonucleic acid by highperformance liquid chromatography. Int J Syst Bacteriol 39, 159-167.

Naser, S. M., Thompson, F. L., Hoste, B., Gevers, D., Dawyndt, P., Vancanneyt, M. \& Swings, J. (2005). Application of multilocus sequence analysis (MLSA) for rapid identification of Enterococcus species based on rpoA and pheS genes. Microbiology 151, 2141-2150.

Pot, B., Vandamme, P. \& Kersters, K. (1994). Analysis of electrophoretic whole-organism protein fingerprints. In Chemical Methods in Prokaryotic Systematics, pp. 493-521. Edited by M. Goodfellow \& A. G. O'Donnell. Chichester: Wiley.

Reuter, G. (1983). Lactobacillus alimentarius sp. nov., nom. rev. and Lactobacillus farciminis sp. nov., nom. rev. Syst Appl Microbiol 4 , 277-279.
Rossello-Mora, R. \& Amann, R. (2001). The species concept for prokaryotes. FEMS Microbiol Rev 25, 39-67.

Scheirlinck, I., Van der Meulen, R., Van Schoor, A., Cleenwerck, I., Huys, G., Vandamme, P., De Vuyst, L. \& Vancanneyt, M. (2007). Lactobacillus namurensis sp. nov., isolated from a traditional Belgian sourdough. Int J Syst Evol Microbiol 57, 223-227.

Stackebrandt, E. \& Goebel, B. M. (1994). A place for DNA-DNA reassociation and $16 \mathrm{~S}$ ribosomal RNA sequence analysis in the present species definition in bacteriology. Int J Syst Bacteriol 44, 846-849.

Thompson, F. L., Hoste, B., Vandemeulebroecke, K. \& Swings, J. (2001). Genomic diversity amongst Vibrio isolates from different sources determined by fluorescent amplified fragment length polymorphism. Syst Appl Microbiol 24, 520-538.

Valcheva, R., Ferchichi, M. F., Korakli, M., Ivanova, I., Gänzle, M. G., Vogel, R. F., Prevost, H., Onno, B. \& Dousset, X. (2006). Lactobacillus nantensis sp. nov., isolated from French wheat sourdough. Int J Syst Evol Microbiol 56, 587-591.

Vancanneyt, M., Naser, S. M., Engelbeen, K., De Wachter, M., Van der Meulen, R., Cleenwerck, I., Hoste, B., De Vuyst, L. \& Swings, J. (2006). Reclassification of Lactobacillus brevis strains LMG 11494 and LMG 11984 as Lactobacillus parabrevis sp. nov. Int J Syst Evol Microbiol 56, 1553-1557.

Versalovic, J., Schneider, M., De Bruijn, F. J. \& Lupski, J. R. (1994). Genomic fingerprinting of bacteria using repetitive sequence-based polymerase chain reaction. Methods Mol Cell Biol 5, 25-40. 